\title{
PENERAPAN PRINSIP PEMBUKTIAN HUKUM PERDATA FORMIL DALAM ARBITRASE BERDASARKAN UNDANG-UNDANG NOMOR 30 TAHUN 1999
}

\author{
Kunti Kalma Syita \\ k.kalmasyita@yahoo.co.id \\ Junior Associate KJD Law Firm
}

\begin{abstract}
In the dispute resolution mechanism both litigation and non-litigation such as arbitrary, proofing evidence process plays essential role to reconstruct the real occurrence in order to seek the truth. Proofing principles that is used in Indonesian arbitrary process is based on the Law number 30 year 1999 on arbitrary and alternative dispute resolution that is lex arbitri for Indonesia. Arbitrary is part of formal civil law, therefore its proofing principles is basically the same with the dispute resolution trough litigation. The Law number 30 year 1999 shows that Even though Indonesia is a civil law jurisdiction, there are some common law principles that are accommodated in the arbitrary process. Using conceptual and statute approach, this article attempts to look at proofing principles may arise in arbitrary mechanism based on the law mentioned and based on the actual practice.
\end{abstract}

Keywords : arbitrary, proofing principles, civil procedural law.

\begin{abstract}
Abstrak
Prinsip umum pembuktian memegang peranan penting dalam proses penyelesaian sengketa perkara perdata baik yang dilakukan melalui litigasi maupun arbitrase, prinsip-prinsip tersebut dijadikan sebagai acuan dalam proses pembuktian yang bertujuan untuk merekonstruksi kejadian pada masa lalu sebagai suatu kebenaran. Prinsip pembuktian yang berlaku dalam arbitrase merujuk pada Undang-Undang Nomor 30 Tahun 1999 tentang Arbitrase dan Alternatif Penyelesaian Sengketa (UU No. 30/1999), dimana undangundang tersebut berposisi sebagai lex arbitri di Indonesia. Arbitrase merupakan bagian dari hukum perdata formil, sehingga prinsip pembuktian yang berlaku pada dasarnya sama dengan prinsip pembuktian yang berlaku dalam penyelesaian sengketa melalui litigasi; namun, ketentuan dalam UU No. 30/1999 menunjukkan bahwa prinsip pembuktian yang berlaku dalam arbitrase terdapat prinsip yang justru lebih umum diterapkan dalam sistem hukum common law. Penelitian ini menggunakan pendekatan konseptual dan pendekatan perundang-undangan untuk mengetahui prinsip pembuktian yang berlaku dalam arbitrase berdasarkan UU No. 30/1999, serta menganalisa kemungkinan adanya potensi permasalahan yang terjadi dalam prakteknya.
\end{abstract}

Kata Kunci: arbitrase, prinsip pembuktian, hukum acara perdata, 


\section{Pendahuluan}

Sistem hukum yang berlaku di Indonesia adalah sistem hukum civil law. Sistem hukum ini diterapkan di Indonesia sebagai akibat dari penjajahan Belanda terdahulu. Sistem hukum civil law memberikan kemungkinan dua macam cara untuk menyelesaikan sengketa perdata yang timbul antara para pihak yang berselisisih, pertama ialah penyelesaian sengketa melalui pengadilan (litigasi), dan kedua ialah penyelesaian sengketa di luar pengadilan (nonlitigasi) yaitu salah satunya dengan melalui arbitrase.

Penyelesaian sengketa melalui pengadilan merupakan cara penyelesaian sengketa yang paling umum dan dikenal oleh masyarakat. Namun, apabila dilihat dari sejarah hukum di Indonesia, pranata arbitrase sesungguhnya telah dikenal sejak tahun 1894, yaitu sejak Pemerintah Hindia Belanda memberlakukan Kitab Undang-Undang Hukum Acara Perdata (Reglement op de Burgelijke Rechtvordering/Rv). Ketentuan mengenai penyelesaian sengketa melalui pranata arbitrase ini diatur dalam Pasal 615 sampai dengan Pasal $651 \mathrm{Rv}$ tersebut. ${ }^{1}$

Rv merupakan hukum acara yang diperuntukkan bagi golongan penduduk Eropa. Pada zaman penjajahan Hindia Belanda penduduk Indonesia terbagi menjadi beberapa golongan penduduk yang didasarkan pada Pasal 131 dan Pasal 163 Indische Staatsregeling (IS). Berdasarkan pasal tersebut, penggolongan penduduk di Indonesia ditetapkan menjadi golongan penduduk Eropa, golongan penduduk Bumiputera, dan golongan penduduk Tionghoa dan Timur Asing. Bagi golongan penduduk Eropa berlaku hukum barat, sedangkan bagi golongan penduduk Bumiputera berlaku hukum adatnya masing-masing atau dapat juga berlaku hukum barat jika ada kepentingan umum dan kepentingan sosial yang dibutuhkan. Bagi golongan penduduk Tionghoa dan Timur Asing berlaku hukum barat dengan beberapa pengecualian. ${ }^{2}$ Adanya pembedaan golongan penduduk tersebut, maka terdapat pula pembedaan perlakuan hukum. Sehingga untuk golongan penduduk Bumiputera hukum acara yang dipergunakan bukanlah Rv, melainkan yang dipergunakan adalah Herziene Inlandsch Reglement (HIR) untuk daerah-daerah di pulau Jawa dan Madura, sedangkan untuk daerah-daerah di luar pulau Jawa dan Madura yang dipergunakan adalah Rechtsreglement Buitengewesten (RBg).

Oleh karena itu, untuk mengetahui aturan mengenai hukum arbitrase dalam tata hukum Indonesia, landasan hukumnya bertitik tolak dari Pasal 377 HIR dan Pasal 705 RBg yang mengatur "jika orang Indonesia dan orang Timur Asing menghendaki perselisihan mereka diputuskan oleh juru pisah maka mereka wajib menuruti peraturan pengadilan perkara yang berlaku bagi bangsa Eropa." Namun, karena dalam HIR maupun RBg tidak terdapat aturan lebih lanjut tentang arbitrase, maka untuk mengisi kekosongan aturan tentang arbitrase, Pasal 377 HIR atau Pasal 705 RBg langsung menunjuk aturan pasal-pasal arbitrase yang terdapat

\footnotetext{
1 Gunawan Widjaja dan Ahmad Yani, Hukum Arbitrase, RajaGrafindo Persada, Jakarta, 2003 (selanjutnya disingkat Gunawan Widjaja), h. 11.

2 Ibid., h. 12.
} 
dalam Rv. Pasal 377 HIR atau Pasal 705 RBg tersebut merupakan pasal yang menyatakan adanya penundukan diri terhadap hukum barat yang berkaitan dengan proses beracara untuk menyelesaikan sengketa melalui "juru pisah" atau arbitrase di dalam Rv. Hal itu terlihat dalam kalimat: "wajib menuruti peraturan pengadilan perkara yang berlaku bagi bangsa Eropa." Dalam Pasal 377 HIR tersebut terlihat bahwa dimungkinkan dan diperbolehkan bagi para pihak yang bersengketa untuk membawa dan menyelesaikan perkara yang timbul melalui jalur non-litigasi.

Pembaharuan Hukum Arbitrase di Indonesia terus dilakukan karena adanya krisis ekonomi yang pernah terjadi di Indonesia. Pembaharuan ini dilakukan untuk memulihkan kepercayaan investor di dunia bisnis pada era 1997-2000. Pembaharuan perundang-undangan mengenaiarbitrase terwujud dengan diundangkannya dan sekaligus diberlakukannya Undang-Undang Nomor 30 Tahun 1999 tentang Arbitrase dan Alternatif Penyelesaian Sengketa pada tanggal 12 Agustus 1999.

Mekanisme penyelesaian sengketa yang termasuk dalam alternatif penyelesaian sengketa berdasarkan Pasal 1 angka 10 UU No. 30/1999 yaitu penyelesaian di luar pengadilan dengan cara konsultasi, negosiasi, mediasi, konsiliasi, atau penilaian ahli. Sedangkan pengertian arbitrase diatur dalam Pasal 1 angka 1 UU No. 30/1999, yaitu yang dimaksud dengan arbitrase adalah cara penyelesaian suatu sengketa perdata di luar peradilan umum yang didasarkan pada perjanjian arbitrase yang dibuat secara tertulis oleh para pihak yang bersengketa. Suyud Margono berpendapat bahwa proses penyelesaian sengketa terdapat dua macam, yaitu proses adjudikasi (adjudicative processes) dan proses konsensus (consensus processes). Penyelesaian sengketa yang termasuk dalam penyelesaian sengketa dengan proses adjudikasi adalah penyelesaian sengketa melalui litigasi dan arbitrase, sedangkan yang termasuk dalam penyelesaian sengketa dengan proses konsensus adalah penyelesaian sengketa melalui negosisasi, mediasi, konsiliasi, dan sebagainya.

Di dalam arbitase, para pihak menyetujui untuk menyelesaikan sengketanya kepada pihak netral yang mereka pilih untuk membuat keputusan. Arbitrase adalah salah satu bentuk adjudikasi privat. Dalam beberapa hal, arbitrase mirip dengan adjudikasi publik dan samasama memiliki beberapa keuntungan dan kelemahan. Riskin dan Westbrook mengatakan, "Arbitration is form of adjudication in which the neutral decision maker is not a judge or an official of an administrative agency. There is no single, comprehensive definition of arbitration that accurately describes all arbitration system. ${ }^{3}$ Dikarenakan litigasi dan arbitrase sama-sama merupakan proses adjudikasi, maka sebenarnya proses penyelesaian sengketa yang dilakukan melalui arbitrase tidak jauh berbeda jika dibandingkan dengan penyelesaian sengketa melalui proses litigasi.

Perbedaan arbitrase dengan litigasi melalui pengadilan adalah dilibatkannya litigasi sengketa pribadi dalam arbitrase. Sifat pribadi dari arbitrase memberikan keuntungan-

3 Suyud Margono, Op.Cit., h. 25,dikutip dari Riskin and Westbrook, Dispute Resolution and Lawyer, American Casebook Series (St. Paul: West Publishing Company. 1987), p. 250. 
keuntungan melebihi adjudikasi melalui pengadilan negeri. Arbitrase pada dasarnya menghindari pengadilan. Dalam kaitan ini, dibandingkan dengan adjudikasi publik, arbitrase lebih memberikan kebebasan, pilihan, otonomi, dan kerahasiaan kepada para pihak yang bersengketa. ${ }^{4}$ Jika melihat pada kenyataan bahwa penyelesaian sengketa melalui pengadilan seringkali membutuhkan waktu yang relatif lama dan berlarut-larut, serta peradilan yang ada di Indonesia saat ini dianggap kurang dapat memenuhi rasa keadilan di masyarakat, penyelesaian sengketa melalui arbitrase dapat dikatakan memiliki keunggulan jika dibandingkan penyelesaian sengketa melalui pengadilan.

Mengutip penjelasan umum UU No. 30/1999, pada umumnya dikatakan bahwa pranata arbitrase mempunyai kelebihan dibandingkan dengan pranata peradilan, yaitu antara lain: a) Dijamin kerahasiaan sengketa para pihak; b) Dapat dihindari kelambatan yang diakibatkan karena hal prosedural dan administratif; c) Para pihak dapat memilih arbiter yang menurut keyakinannya mempunyai pengetahuan, pengalaman serta latar belakang yang cukup mengenai masalah yang disengketakan, jujur dan adil; d) Para pihak dapat menentukan pilihan hukum untuk menyelesaikan masalahnya serta proses dan tempat penyelenggaraan arbitrase; dan e) Putusan arbiter merupakan putusan yang mengikat para pihak dan dengan melalui tata cara (prosedur) sederhana saja ataupun langsung dapat dilaksanakan. ${ }^{5}$

Gary Goodpaster, Felix O. Soebagjo, dan Fatmah Jatim, menyebutkan ada beberapa alasan memilih arbitrase, yaitu: 1) Kebebasan, kepercayaan, dan keamanan; 2) Keahlian (expertise): 3) Cepat dan hemat biaya; 4) Bersifat rahasia; 5) Bersifat non-preseden; 6) Kepekaan arbiter; 6) Pelaksanaan Keputusan; 7) Kecenderungan yang modern. ${ }^{6}$

Sekalipun proses penyelesaian sengketa yang dilakukan melalui arbitrase tidak jauh berbeda dengan penyelesaian sengketa melalui proses litigasi dan dianggap memiliki berbagai keunggulan, tidak kemudian menjadikan arbitrase menjadi salah satu cara penyelesaian sengketa yang unggul tanpa cela. Pada kenyataannya, banyak hambatan-hambatan yang dihadapi dalam proses penyelesaian sengketa melalui arbitrase ini. Hambatan-hambatan tersebut dapat terlihat khususnya dalam hal pemeriksaan sengketa terutama pada tahap pembuktian, misalnya dalam hal menghadirkan saksi-saksi.

Dalam proses litigasi, hakim memiliki kewenangan untuk memaksa saksi untuk hadir dalam persidangan kecuali jika ketidakhadiran yang bersangkutan disebabkan karena adanya alasan yang sah. Sedangkan dalam prosedur pembuktian yang berlaku di arbitrase tidaklah demikian, tidak ada kewenangan bagi arbiter ataupun para pihak untuk memaksa seseorang hadir sebagai saksi. Hambatan-hambatan semacam itu harus segera dicari jalan keluarnya karena hal tersebut berkaitan dengan tahap pembuktian dalam suatu proses penyelesaian sengketa, dimana tahap pembuktian merupakan tahap yang paling penting dalam rangkaian proses penyelesaian sengketa baik melalui litigasi maupun non-litigasi. Tahap inilah yang

4 Ibid.

5 Gunawan Widjaja, Op.Cit., h. 4.

6 Ibid, h. 5. 
paling menentukan bagaimana sebuah putusan akan dijatuhkan. ${ }^{7}$ Oleh karena itu, tahap pembuktian tidak hanya memegang peranan penting dalam proses penyelesaian sengketa di pengadilan saja, tetapi juga dalam proses penyelesaian sengketa melalui arbitrase. Sehingga hal-hal yang menjadi hambatan dalam proses penyelesaian sengketa melalui arbitrase khususnya yang berkaitan dengan tahap pembuktian dalam pemeriksaan sengketa perdata patut untuk diberikan perhatian lebih dan segera dicari jalan keluarnya agar tidak menyebabkan timbulnya masalah baru dalam prosesnya yang diakibatkanadanya kekosongan hukum atau tidak adanya aturan yang jelas untuk menyelesaikan persoalan semacam itu. Untuk mengatasi permasalahan yang berkaitan dengan tahap pembuktian dalam proses penyelesaian sengketa melalui arbitrase ini, maka perlu dielaborasi prinsip pembuktian yang berlaku dalam arbitrase dan bagaimana penerapannya berdasarkan UU No. 30 Tahun 1999.

\section{Pembuktian Dalam Arbitrase berdasarkan Undang-Undnag Nomor 30 Tahun 1999 tetang Arbitrase dan Alternatif Penyelesaian Sengketa}

Arbitrase merupakan bagian dari hukum perdata formil, karena arbitrase juga merupakan penegakan dari hukum perdata materiil yaitu Hukum Dagang. Hal ini dapat dilihat pada ketentuan yang ada dalam Pasal 5 jo. Penjelasan Pasal 66 huruf b UU No. 30/1999, yang mengatur bahwa sengketa-sengketa perdata yang dapat diselesaikan melalui arbitrase adalah sengketa yang masuk dalam ruang lingkup hukum perdagangan.

Arbitrase adalah salah satu cara penyelesaian sengketa di luar pengadilan yang didasarkan atas kesepakatan para pihak atau bersifat kontraktual. Sifat arbitrase yang demikian terlihat dalam pengertian arbitrase yang diatur dalam Pasal 1 angka 1 UU No. 30/1999 yang mengatur bahwa arbitrase merupakan cara penyelesaian suatu sengketa di luar peradilan umum yang didasarkan atas perjanjian tertulis dari pihak yang bersengketa. Perjanjian tertulis tersebut mengikat para pihak yang menandatanganinya, bahkan Pasal 3 UU No. 30/1999 juga dengan tegas mengatur bahwa Pengadilan Negeri tidak memiliki kewenangan untuk menyelesaikan sengketa apabila para pihak telah terikat perjanjian arbitrase. $^{8}$

Perjanjian tertulis yang dimaksud di dalam Pasal 1 angka 1 UU No. 30/1999 adalah perjanjian arbitrase, yaitu suatu kesepakatan berupa klausula arbitrase yang tercantum dalam perjanjian tertulis yang dibuat para pihak sebelum timbul sengketa, atau surat perjanjian arbitrase tersendiri yang dibuat para pihak setelah timbul sengketa. Adanya perjanjian ini melahirkan kompetensi absolut bagi para pihak untuk menentukan sendiri cara penyelesaian sengketa yang dikehendaki, karena dengan adanya perjanjian arbitrase tersebut telah

\footnotetext{
M. Yahya Harahap, Hukum Acara Perdata tentang: Gugatan, Persidangan, Penyitaan, Pembuktian, dan Putusan Pengadilan, Sinar Grafika, Jakarta, 2009 (selanjutnya disingkat M. Yahya Harahap II), h. 496.

8 Huala Adolf (Disusun oleh Tim di bawah pimpinan Huala Adolf), Analisis dan Evaluasi Hukum Penyelesaian Sengketa Melalui Arbitrase (UU No. 30 Tahun 1999), Badan Pembinaan Hukum Nasional Departemen Hukum dan HAM RI, Jakarta, 2006 (selanjutnya disingkat Huala Adolf I), h. 11.
} 
meniadakan hak para pihak untuk mengajukan penyelesaian sengketa yang dimuat dalam perjanjian pokok ke Pengadilan Negeri. ${ }^{9}$ Perjanjian arbitrase ini menjadi begitu penting karena merupakan dasar bagi para pihak untuk menyelesaikan sengketa melalui arbitrase. Untuk itu, hal-hal mengenai cara penyelesaian sengketa yang dikehendaki oleh para pihak harus tertulis secara tegas dalam perjanjian arbitrase.

Dari ketentuan dalam Pasal 1 angka 4 UU No. 30/1999 maka dikenal adanya dua bentuk klausula arbitrase. Bentuk pertama adalah Pactum de Compromittendo. Dalam klausula arbitrase yang berbentuk seperti ini para pihak bersepakat untuk menyelesaikan sengketa yang mungkin timbul, untuk diselesaikan melalui arbitrase. Sehingga pada saat para pihak bersepakat, sengketa sama sekali belum terjadi. ${ }^{10}$ Sedangkan bentuk yang kedua yaitu akta kompromis. Akta kompromis dibuat pada saat sengketa terjadi. Hal ini dapat terjadi apabila setelah para pihak mengadakan perjanjian pokok, dan perjanjian tersebut sudah berjalan, kemudian dalam perjalanannya terjadi sengketa, padahal sebelumnya para pihak tidak mengadakan persetujuan arbitrase. Maka, jika para pihak kemudian menginginkan sengketa tersebut diselesaikan melalui arbitrase dapat dibuat perjanjian arbitrase yang berbentuk akta kompromis ini. ${ }^{11}$

Sifat kontraktual yang melekat pada arbitrase ini juga berpengaruh dalam proses pembuktian, dimana dalam penyelesaian sengketa melalui arbitrase dikenal adanya perjanjian pembuktian. Prinsip perjanjian pembuktian ini juga dikenal dalam pembuktian pada sengketa perdata melalui litigasi.Namun, sama halnya dalam arbitrase yang hanya dapat menyelesaikan sengketa-sengketa yang masuk dalam ruang lingkup hukum perdagangan, perjanjian pembuktian dalam penyelesaian sengketa perdata melalui litigasi juga hanya diperbolehkan dalam bidang sengketa dagang dan komersial saja. Sedangkan untuk bidang sengketa yang menyangkut kekeluargaan atau perkawinan tidak diperbolehkan untuk mengadakan perjanjian pembuktian.

Jika pada dasarnya dalam proses pembuktian arbitrase memiliki kemiripan prinsip dengan proses pembuktian dalam litigasi, maka secara umum dapat dikatakan bahwa jalannya pemeriksaan dalam arbitrase juga tidak akan jauh berbeda dengan jalannya proses pemeriksaan perkara perdata dalam pranata peradilan pada umumnya. ${ }^{12} \mathrm{Hal}$ ini dikarenakan proses pemeriksaan sengketa dalam arbitrase pada dasarnya menggunakan ketentuanketentuan yang terdapat dalam hukum acara perdata pada umumnya termasuk juga dalam hal pembuktian. Hal paling mendasar yang dapat membedakan keduanya adalah berkaitan dengan salah satu keunggulan dari penyelesaian sengketa melalui arbitrase yaitu kebebasan para pihak dalam menentukan kehendaknya yang berkaitan dengan penyelesaian sengketa.

9 Gunawan Widjaja, Op. Cit., h. 49.

10 M. Yahya Harahap, Arbitrase ditinjau dari: RV, Peraturan Prosedur Bani, ICSID, UNCITRAL Arbitration Rules, Convention of the Recognition and Enforcement of Foreign Arbitral Award, Perma No. 1 Tahun 1990, Sinar Grafika, Jakarta, 2003 (selanjutnya disingkat M. Yahya Harahap I), h. 65-66.

11 Ibid.

12 Gunawan Widjaja,Op. Cit., h. 81. 
Pasal 31 ayat (1) UU No. 30/1999 menegaskan bahwa para pihak dalam suatu perjanjian yang tegas dan tertulis, bebas untuk menentukan acara arbitrase yang digunakan dalam pemeriksaan sengketa, sepanjang tidak bertentangan dengan ketentuan dalam UU No. 30/1999.

Berkaitan dengan kebebasan tersebut, UU No. 30/1999 mengatur mengenai dua macam cara penyelesaian sengketa melalui arbitrase. Hal ini diatur dalam Pasal 6 ayat (9), yaitu penyelesaian sengketa melalui arbitrase ad-hoc dan melalui lembaga arbitrase tersendiri (arbitrase institusional). Arbitrase ad-hoc adalah arbitrase yang dibentuk khusus untuk menyelesaikan atau memutus perselisihan tertentu. Arbitrase ini bersifat insidental dan jangka waktunya tertentu sampai sengketa itu diputuskan. Sedangkan arbitrase institusional adalah lembaga atau badan arbitrase yang bersifat permanen. Lembaga ini sengaja didirikan untuk menampung perselisihan yang timbul dari perjanjian. ${ }^{13}$ Untuk dapat memilih cara penyelesaian sengketa melalui arbitrase ad hoc atau arbitrase institusional, para pihak diberi kebebasan untuk menyepakati kehendaknya, dengan ketentuan harus tertulis dalam klausula arbitrase baik dalam bentuk Pactum de Compromittendo atau akta kompromis.

Penyelesaian sengketa melalui lembaga arbitrase termasuk juga dalam hal proses pembuktian sebenarnya dilakukan menurut peraturan dan acara dari lembaga pilihan yang disepakati para pihak, hal ini secara tegas diatur dalam Pasal 34 ayat (2) UU No. 30/1999. Akan tetapi khusus untuk arbitrase ad-hoc, Pasal 31 ayat (2) UU No. 30/1999 mengatur apabila para pihak tidak menentukan sendiri ketentuan acara arbitrase yang akan digunakan dalam pemeriksaan, sedangkan arbiter atau majelis arbitrase telah terbentuk, maka penyelesaian sengketa diserahkan kepada arbiter atau majelis arbitrase tersebut untuk diperiksa dan diputus dengan menggunakan ketentuan dalam UU No. 30/1999. ${ }^{14}$

Selanjutnya, membahas mengenai pembuktian tentu tidak akan lepas dari pembahasan mengenai alat bukti dan nilai kekuatan pembuktian dari masing-masing jenis alat bukti. Untuk mengetahui alat bukti apa saja yang dapat diajukan dalam proses pembuktian dalam arbitrase, maka perlu merujuk pada UU No. 30/1999. Selain merujuk pada UU No. 30/1999, mengenai alat bukti dan nilai kekuatan pembuktiannya juga perlu merujuk pada BW dan HIR, karena kedua undang-undang tersebut berkedudukan sebagai lex generalis dari UU No. 30/1999.

Acuan pertama untuk menentukan alat bukti yang sah dalam pemeriksaan sengketa melalui arbitrase adalah alat bukti yang ditentukan dalam peraturan perundang-undangan tertentu dan penetapan acuan tersebut digantungkan pada perjanjian arbitrase. ${ }^{15}$ Dalam arbitrase, hal-hal yang berkaitan dengan alat bukti dan nilai kekuatan pembuktian dalam penerapannya bisa beragam sesuai dengan kesepakatan para pihak yang dituangkan dalam perjanjian arbitrase. Jika para pihak sepakat untuk tunduk pada hukum acara perdata Indonesia

\footnotetext{
13 Ibid., h. 55-56.

14 Ibid., h. 83.

15 Ibid.
} 
maka mengenai alat bukti yang sah dan nilai pembuktiannya harus merujuk pada BW sebagai hukum materiil dan HIR atau RBg sebagai hukum formilnya. Untuk itu, sekalipun para pihak memiliki kebebasan dalam menyepakati alat bukti dan nilai pembuktiannya, namun kebebasan tersebut tetap dibatasi dengan ketentuan yang ada dalam BW, HIR dan UU No. 30/1999.

Ketentuan mengenai alat bukti yang sah, di dalamBW diatur secara tegas. Hal tersebut diatur dalam Pasal 1866 BW yang menyebutkan bahwa alat bukti yang sah adalah: 1) Bukti tulisan; 2) Bukti dengan saksi-saksi; 3) Persangkaan-persangkaan; 4) Pengakuan; dan 5) Sumpah. Begitu pula di dalam HIR, melalui pasal 164 HIR juga ditegaskan mengenai apa saja yang termasuk sebagai alat bukti yang sah yaitu: 1) Bukti tulisan; 2) Bukti saksi; 3) Bukti persangkaan; 4) Bukti pengakuan; dan 5) Sumpah.

Ketentuan mengenai alat-alat bukti tersebut diurut berdasarkan alat bukti apa yang diutamakan terlebih dahulu, sehingga tidak diperbolehkan untuk menerapkannya secara acak. Alat bukti yang diutamakan harus didasarkan pada urutan dari alat-alat bukti yang diatur secara limitatif oleh undang-undang. Dari ketentuan yang ada di dalam BW dan HIR tersebut dapat disimpulkan bahwa dalam pembuktian sengketa perdata, alat bukti yang diutamakan adalah bukti tulisan.

Namun jika merujuk pada UU No. 30/1999, pengaturan mengenai alat bukti yang sah dalam undang-undang tersebut berbeda dengan pengaturan mengenai alat bukti yang ada dalam BW dan HIR. Dalam UU No. 30/1999, pengaturan mengenai alat bukti tidak diatur secara tegas dengan menyebutkan secara limitatif tentang apa saja yang bisa dijadikan sebagai alat bukti, namun pengaturannya tersebar dalam beberapa pasal yang secara implisit dapat dikatakan mengakui hal-hal tertentu sebagai alat bukti yang dapat diajukan dalam proses pembuktian dalam pemeriksaan sengketa melalui arbitrase.

Alat bukti pertama yaitu alat bukti tulisan berupa surat atau dokumen. Hal ini bisa ditafsirkan dari ketentuan yang ada dalam beberapa pasal di dalam UU No. 30/1999. Salah satunya adalah Pasal 35, dalam pasal tersebut diatur bahwa arbiter atau majelis arbitrase dapat memerintahkan agar setiap dokumen atau bukti disertai dengan terjemahan ke dalam bahasa yang ditetapkan oleh arbiter atau majelis arbitrase. Selain itu, pengakuan undangundang secara tidak langsung terhadap alat bukti tulisan berupa surat atau dokumen juga bisa dilihat dalam Pasal 70. Pasal tersebut mengatur secara limitatif dasar-dasar yang dapat dipakai untuk mengajukan pembatalan putusan arbitrase. Pada salah satu poin dalam Pasal 70 yaitu pada poin a disebutkan bahwa surat atau dokumen yang diajukan dalam pemeriksaan, setelah putusan dijatuhkan, diakui atau dinyatakan palsu. Dengan mengacu pada pasal-pasal tersebut maka bisa dikatakan bahwa UU No. 30/1999 juga mengakui adanya alat bukti tulisan yang berupa surat atau dokumen.

Alat bukti selanjutnya yang diakui secara implisit dalam UU No. 30/1999 adalah alat bukti saksi dan saksi ahli. Pada pasal 49 ayat (1) UU No. 30/1999 disebutkan bahwa atas perintah arbiter atau majelis arbitrase atau atas permintaan para pihak, dapat dipanggil 
seorang saksi atau lebih atau seorang saksi ahli atau lebih untuk didengar keterangannya. Dari isi pasal tersebut maka bisa disimpulkan bahwa dalam proses pembuktian dalam arbitrase, saksi merupakan salah satu alat bukti yang diakui dalam arbitrase, dan keterangan saksi ahli pun juga dapat digunakan sebagai bahan pertimbangan.

Bicara mengenai pembuktian dan alat bukti tentu tidak terlepas dari nilai kekuatan pembuktian yang melekat pada masing-masing jenis alat bukti.Sebelumnya sudah disebutkan, jika mengacu pada BW dan HIR, alat bukti yang sah dalam hukum acara perdata adalah bukti tulisan, bukti saksi, bukti persangkaan, bukti pengakuan, dan sumpah. Pada setiap jenis alat bukti tersebut melekat nilai kekuatan pembuktian yang sudah ditentukan di dalam undang-undang baik dalam hukum materiil maupun hukum formil.

Berbeda halnya dengan pengaturan di dalam BW dan HIR yang mengatur secara tegas mengenai alat bukti yang sah dan juga nilai kekuatan pembuktian yang melekat pada setiap jenis alat bukti, UU No. 30/1999 tidak mengatur hal tersebut secara tegas. Untuk mengetahui jenis alat bukti yang diakui hanya dapat dilihat dengan menafsirkan pasal-pasal lainnya yang tersebar dalam undang-undang tersebut. Sementara pengaturan mengenai nilai kekuatan pembuktian ini tidak diatur, bahkan secara implisit sekalipun, baik mengenai nilai kekuatan pembuktian bukti tulisan maupun bukti saksi dan saksi ahli. Tidak adanya aturan mengenai nilai kekuatan pembuktian ini bisa saja disebabkan adanya prinsip kebebasan yang dikenal dalam arbitrase bahawa para pihak dalam arbitrase memiliki kebebasan untuk menyepakati alat bukti yang dapat diajukan dan bebas pula untuk menyepakati nilai kekuatan pembuktian dari masing-masing jenis alat bukti tersebut. ${ }^{16}$

Selanjutnya, berkaitan dengan proses pemeriksaan pembuktian tentu akan sangat bergantung pada acara yang digunakan. Pada umumnya lex arbitri tidak mengatur secara khusus mengenai acara yang berlaku di hadapan arbiter atau majelis arbitrase, karena biasanya hal tersebut didasarkan pada kesepakatan para pihak atau jika tidak disepakati oleh para pihak, maka acara yang berlaku ditentukan oleh arbiter atau majelis arbitrase. Aturan mengenai acara yang dimaksud adalah pengaturan yang antara lain berkaitan dengan pendaftaran permohonan, proses jawab jinawab dan termasuk juga mengenai pembuktian. Sebagai bahan perbandingan, jika melihat ketentuan-ketentuan dalam undangundang arbitrase Prancis yang tertuang dalam Decree No. 2011-48 of 13 January 2011 tidak terlihat adanya ketentuan yang secara khusus mengatur mengenai proses beracara dalam arbitrase. Proses beracara yang dimaksud khususnya adalah aturan mengenai proses jawab jinawab. Berkenaan dengan acara yang digunakan, undang-undang arbitrase Prancis tersebut memang mengaturnya dalam Chapter III mengenai The Arbitral Proceedings. Namun, dalam pengaturan tersebut tidak terlihat adanya ketentuan mengenai pendaftaran permohonan, atau proses jawab jinawab beserta jangka waktunya. Undang-undang arbitrase Prancis tersebut hanya mengatur yang pada intinya, mengenai proses jawab jinawab beserta

16 M. Yahya Harahap II, Op. Cit., h. 516. 
jangka waktunya penentuannya didasarkan pada kesepakatan para pihak atau ditentukan oleh arbiter atau majelis arbitrase. ${ }^{17}$ Selain itu, undang-undang arbitrase Malaysia yaitu Act 646 Arbitration Act 2005 juga mengatur demikian, undang-undang tersebut mengatur dalam Chapter 5 mengenai Conduct of Arbitral Proceedings tapi tidak mengatur mengenai proses jawab jinawab. ${ }^{18}$

Senada dengan kedua undang-undang tersebut, undang-undang arbitrase Singapura yaitu Singapore Act Arbitration 2001 juga mengatur mengenai Arbitral Proceedings pada Part VII, namun juga tidak terlihat adanya ketentuan mengenai proses beracara khususnya dalam hal proses jawab jinawab. ${ }^{19}$ Hal ini berbeda dengan UU No. 30/1999 yang menentukan secara tegas dalam pasal-pasalnya mengenai proses jawab jinawab beserta jangka waktu pada setiap tahapannya.

Penyelesaian sengketa melalui lembaga arbitrase termasuk juga dalam hal proses pembuktian pada dasarnya dilakukan menurut peraturan dan acara dari lembaga yang dipilih dan disepakati oleh para pihak. Akan tetapi khusus untuk arbitrase ad-hoc, UU No. 30/1999 mengatur apabila para pihak tidak menentukan sendiri ketentuan acara arbitrase yang akan digunakan dalam pemeriksaan, maka penyelesaian sengketa diserahkan kepada arbiter atau majelis arbitrase untuk diperiksa dan diputus dengan menggunakan ketentuan dalam UU No. 30/1999. Untuk itu, apabila acara yang digunakan tidak ditentukan oleh para pihak, maka arbiter atau majelis arbitrase dalam arbitrase ad-hoc yang akan menentukannya dengan mengacu pada ketentuan UU No. 30/1999 khususnya dengan merujuk pada ketentuan yang diatur dalam Bab IVUU No. 30/1999.

Pada proses pemeriksaan melalui arbitrase, khususnya yang mengacu pada ketentuan yang ada dalam UU No. 30/1999, semua pemeriksaan sengketa oleh arbiter atau majelis arbiter dilakukan secara tertutup. Hal ini ditegaskan dalam Pasal 27 undang-undang tersebut. Pemeriksaan yang dilakukan secara tertutup nyatanya menyimpang dari ketentuan acara perdata yang berlaku dalam proses litigasi, dimana pada prinsipnya adalah terbuka untuk umum. ${ }^{20}$ Namun dalam Penjelasan Pasal 27 ditegaskan bahwa pemeriksaan secara tertutup adalah untuk menegaskan sifat kerahasiaan dari penyelesaian sengketa melalui arbitrase.

Selain itu, pemeriksaan sengketa dalam arbitrase harus dilakukan secara tertulis, termasuk juga dalam hal pemeriksaan saksi maupun saksi ahli atau yang biasa disebut dengan affidavit.Sedangkan pemeriksaan sengketa melalui litigasi tidaklah demikian, sistem peradilan di Indonesia justru tidak mengenal adanya affidavit. HIR juga sama sekali tidak mengatur mengenai kemungkinan adanya affidavit ini, ketentuan dalam HIR secara tegas mengatur bahwa saksi yang hendak memberikan keterangan harus disumpah terlebih dahulu di muka pengadilan, ketentuan ini dapat dilihat dalam Pasal 147 HIR. Kemungkinan adanya

\footnotetext{
17 French Law on Arbitration, Decree No. 2011-48 of 13.

18 Law of Malaysia, Act 646 Arbitration Act 2005.

19 Singapore Act Arbitration 2001.

20 M. Yahya Harahap II, Op. Cit., h. 71-72.
} 
affidavit dalam proses penyelesaian sengketa melalui arbitrase didasarkan pada ketentuan mengenai pemeriksaan sengketa dalam arbitrase yang dilakukan secara tertulis, hal ini diatur secara tegas dalam Pasal 36 UU No. 30/1999. Pemeriksaan secara lisan hanya bisa dilakukan apabila disetujui oleh para pihak dan dianggap perlu oleh arbiter atau majelis arbitrase.

\section{Prinsip Pembuktian Yang Berlaku Dalam Arbitrase Berdasarkan undang-Undang Nomor 30 Tahun 1999}

Jika membahas mengenai arbitrase seringkali banyak menyebut mengenai arbiter. Dapat dikatakan arbitrase merupakan "wadah", sedangkan arbiter adalah orang yang ditunjuk dan diangkat untuk melaksanakan fungsi dan kewenangan arbitrase. ${ }^{21}$ UU No. 30/1999 mengatur mengenai pengertian arbiter, dalam Pasal 1 angka 7 disebutkan bahwa "arbiter adalah seorang atau lebih yang dipilih oleh para pihak yang bersengketa atau yang ditunjuk oleh Pengadilan Negeri atau lembaga arbitrase, untuk memberikan putusan mengenai sengketa tertentu yang diserahkan penyelesaiannya melalui arbitrase." Dengan melihat pengertian arbiter yang diatur dalam UU No. 30/1999 tersebut maka dapat disimpulkan bahwa arbiter dalam arbitrase memiliki kedudukan yang sama dengan hakim dalam litigasi, yaitu sama-sama memiliki kewenangan untuk memutus sengketa. Arbiter memiliki kedudukan layaknya seorang hakim setelah ia dipilih oleh para pihak, dengan begitu maka arbiter memiliki kewenangan untuk memutus sengketa berdasarkan fakta-fakta sah yang diserahkan kepadanya. Untuk memperoleh kewenangan tersebut maka harus didasarkan atas kesepakatan para pihak, dan kewenangan itu merupakan sesuatu yang dipercayakan kepadanya oleh para pihak. ${ }^{22}$

Jika dalam hukum acara perdata tugas dan peran hakim bersifat pasif dan hakim hanya terbatas menerima dan memeriksa sepanjang mengenai hal-hal yang diajukan oleh penggugat dan tergugat, maka dalam arbitrase sangat perlu untuk mengetahui bagaimana tugas dan peran arbiter. Jika melihat prinsip umum pembuktian perkara perdata yang demikian, maka tidak salah jika dikatakan bahwa seharusnya tugas dan peran arbiter juga pasif sama halnya dengan sifat hakim dalam proses litigasi. Namun, untuk mengetahui hal tersebut maka perlu mengacu pada ketentuan yang ada dalam UU No. 30/1999.

Jika melihat ketentuan yang ada dalam UU No. 30/1999, dapat dikatakan bahwa ketentuan dalam undang-undang tersebut ternyata tidak sepenuhnya mengarah pada peran arbiter yang bersifat pasif. Ketentuan dalam UU No. 30/1999 menunjukkan adanya kemungkinan diterapkannya prinsip discovery yang sebenarnya lebih umum diterapkan dalam proses pembuktian di negara-negara common law system. ${ }^{23}$

21 M. Yahya Harahap I, Op. Cit., h. 110.

22 Priyatna Abdurrasyid, Arbitrase dan Alternatif Penyelesaian Sengketa (APS): Suatu Pengantar (Edisi Ke-2 Revisi), Fikahati Aneska, Jakarta, 2011 (selanjutnya disingkat Priyatna Abdurrasyid), h. 95.

23 Frans Hendra Winarta, Discovery of Documentary Evidence in International Commercial Arbitration, Proceeding Sixth RAIF Conference On International Arbitration Jimbaran, Bali, Indonesia 5-6 May2012 (selanjutnya disingkat Frans Hendra Winarta), p. 5. 
Frans Hendra Winarta menyatakan:Although discovery of evidence is currently quite common in international commercial arbitrations, such thing is often a new experience for parties domiciled in civil law countries where such discovery is not permitted under local law and for such parties, the discovery process carries obvious risks. ${ }^{24}$ Pada negara-negara yang menganut sistem hukum common law, discovery merupakan tahap yang sangat penting dalam proses pembuktian. Pada tahap discovery para pihak diperbolehkan untuk meminta dokumen-dokumen dan informasi lainnya yang relevan dengan sengketa a quo kepada pihak lainnya. Informasi yang relevan ini sangat berkaitan dengan relevant evidence, dan yang dimaksud dengan relevant evidence adalah "evidence having any tendency to make the existence of any fact that is of consequence to the determination of the action more probable or less probable than it would be without the evidence. "25 Oleh karena itu, dokumen yang diminta seringkali merupakan dokumen yang memiliki peran penting dalam membuktikan adanya suatu fakta, dan dokumen seperti inilah yang biasanya tidak ingin dibuka oleh pihak yang bersangkutan, karena sifatnya yang penting dan biasanya juga bersifat rahasia.

Selain itu para pihak juga dapat meminta "oral deposition testimony" dari saksisaksi pada pemeriksaan di pengadilan. Sedangkan dalam sistem hukum civil law hal tersebut tidak diperbolehkan dan dianggap sebagai "penghinaan" terhadap privasi dan kerahasiaan informasi bisnis yang dimiliki oleh para pihak. ${ }^{26} \mathrm{HIR}$ sama sekali tidak mengatur mengenai adanya kemungkinan discovery, tidak ada ketentuan di dalam HIR yang menyatakan bahwa para pihak yang bersengketa memiliki hak untuk meminta dokumen kepada pihak lain, selain itu HIR juga tidak memberikan kewenangan kepada hakim untuk meminta para pihak untuk mengajukan bukti-bukti. ${ }^{27}$ Namun, kemungkinan dilakukannya discovery justru terlihat pada beberapa pasal dalam UU No. 30/1999, contohnya dalam Pasal 47 ayat (3) yang mengatur bahwa arbiter atau majelis arbitrase berhak untuk meminta kepada para pihak untuk mengajukan penjelasan tambahan secara tertulis, dokumen atau bukti lainnya yang dianggap perlu dalam jangka waktu yang ditentukan oleh arbiter atau majelis arbitrase. Selain itu, Pasal 49 ayat (1) juga mengatur bahwa arbiter atau majelis arbitrase dapat memanggil seorang saksi atau lebih atau seorang saksi ahli atau lebih untuk didengar keterangannya.

Pasal berikutnya yang menunjukkan adanya discovery adalah Pasal 70 yang mengatur mengenai pembatalan putusan arbitrase. Dalam pasal tersebut diatur bahwa terhadap putusan arbitrase para pihak dapat mengajukan permohonan pembatalan apabila putusan tersebut diduga mengandung unsur-unsur sebagai berikut: a) surat atau dokumen yang diajukan dalam pemeriksaan, setelah putusan dijatuhkan, diakui palsu atau dinyatakan palsu; b) setelah putusan diambil ditemukan dokumen yang bersifat menentukan, yang disembunyikan oleh

${ }^{24}$ Ibid., p. 9.

25 Irving Younger, Michael Goldsmith, David A. Sonenshein, Principles of Evidence: Third Edition, Anderson Publishing Co., Ohio, 1997, p. 36.

26 Ibid, p. 5.

27 Ibid., p. 10. 
pihak lawan; atau c) putusan diambil dari hasil tipu muslihat yang dilakukan oleh salah satu pihak dalam pemeriksaan sengketa.

Berdasarkan ketentuan Pasal 70, para pihak dimungkinkan untuk mengajukan permohonan pembatalan putusan arbitrase, namun alasan pengajuan permohonan pembatalan hanya terbatas pada alasan-alasan yang sudah ditentukan di dalam undang-undang. Salah satu alasan yang dapat digunakan sebagai dasar pengajuan permohonan pembatalan yang berkaitan erat dengan prinsip discovery adalah alasan yang terdapat dalam Pasal 70 huruf b yaitu jika setelah putusan diambil ditemukan dokumen yang bersifat menentukan, yang disembunyikan oleh pihak lawan.

Pada prinsip discovery, kewajiban para pihak untuk menunjukkan dan menyerahkan dokumen-dokumen yang terkait dengan sengketa merupakan kewajiban hukum. Dokumendokumen yang dimaksud tidak hanya dokumen yang mendukung para pihak saja, tetapi termasuk semua dokumen yang relevan atau berkaitan dengan sengketa a quo.

Document disclosure under the common law system has the meaning the disclosure of all relevant documents. It is seen as an obligation for a party to produce every single relevant and admissible document in its possession to the court, not merely the one that supports its case and the failure to comply with a disclosure order in litigation proceedings may lead to severe sanctions. This phase commonly executed after the submissons of the parties' claims and defences (which usually do not contain evidence), but before the exchange of witness statements and the commencement of the hearing. ${ }^{28}$

Dokumen-dokumen yang dimaksud adalah sebagai berikut: a) any documents on which the party relies, and b) any documents which adversely affect his own case; adversely affect another party's case, or; support another party's case (CPR 1998 Rule 31.6) ${ }^{29}$

Pada tahap discovery dalam sistem hukum common law, para pihak yang tidak mematuhi kewajiban untuk menunjukkan semua dokumen yang relevan dengan sengketa a quo dapat dikenai sanksi. Sedangkan dalam penyelesaian sengketa perdata melalui arbitrase di Indonesia tidak ada aturan tegas mengenai pengenaan sanksi terhadap upaya menghilangkan barang bukti atau menyembunyikan barang bukti.

Dari uraian tersebut di atas maka dapat dilihat bahwa UU No. 30/1999 memungkinkan adanya discovery yang umumnya justru diterapkan dalam sistem hukum common law. Meskipun pada prinsipnya hakim dalam proses perkara perdata di pengadilan bersifat pasif, namun berdasarkan UU No. 30/1999, arbiter yang bertindak selayaknya hakim dalam proses penyelesaian sengketa melalui arbitrase tidak menunjukkan peran yang sepenuhnya bersifat pasif, dan dalam keadaan tertentu arbiter menunjukkan peran yang lebih aktif dalam proses penyelesaian sengketa. Selain itu juga terlihat bahwa terdapat disharmoni di dalam UU No. 30/1999, karena di dalam civil law system prinsip discovery tidak dikenal sehingga dalam pelaksanaannya khususnya yang berkaitan dengan Pasal 70 huruf b UU No. 30/1999 menjadi

28 Ibid, p. 6.

29 Raymond Emson, Evidence, Macmillan, London, 1999, p. 316. 
sulit untuk diterapkan.

Selanjutnya, berkaitan dengan penerapan salah satu prinsip dalam pembuktian hukum acara perdata yaitu prinsip audi et alteram partem. Pasal 29 ayat (1) UU No. 30/1999 menegaskan bahwa "para pihak yang bersengketa mempunyai hak dan kesempatan yang sama dalam mengemukakan pendapat masing-masing." Pasal tersebut mengatur secara tegas mengenai hak para pihak untuk mengemukakan pendapatnya masing-masing. Hal ini menunjukkan bahwa dalam arbitrase juga menerapkan prinsip audi et alteram partem. Sebagai bahan perbandingan, UNCITRAL Model Law juga mengatur mengenai hal ini melalui ketentuan yang ada dalam Article 18.Article 18 menegaskan mengenai equal treatment of parties, yang isinya kurang lebih sama dengan ketentuan yang ada pada Pasal 29 ayat (1) UU No. 30/1999. Article 18 UNCITRAL Model Law mengatur sebagai berikut "the parties shall be treated with equality and each party shall be given a full opportunity of presenting his case. "30 Dari ketentuan tersebut dapat disimpulkan bahwa UNCITRAL Model Law juga menerapkan prinsip audi et alteram partem.

Selain ditegaskan dalam Article 18, prinsip ini juga tersirat dalam Article 23 ayat (2) UNCITRAL Model Law yaitu berkaitan dengan kesempatan untuk melakukan perubahan atau penambahan statements of claim dan statement of defence. Pasal tersebut merumuskannya sebagai berikut "unless otherwise agreed by the parties, either party may amend or supplement his claim or defence during the course of the arbitral proceedings, unless the arbitral tribunal considers it inappropriate to allow such amendment having regard to the delay in making it." 31 Pasal ini menunjukkan bahwa prinsip tersebut berlaku pada setiap tahap proses pemeriksaan termasuk juga pada pemberian kesempatan untuk mengajukan perubahan atau penambahan pada statements of claim $^{32}$ dan statement of defence. ${ }^{33}$ Kesempatan yang diberikan kepada claimant maupun respondent haruslah seimbang, terlepas dari masing-masing pihak menggunakan kesempatan tersebut sebaikbaiknya atau tidak sama sekali, tidaklah menjadi persoalan. Kesempatan tersebut merupakan hak masing-masing pihak, sehingga tidak dapat dipaksakan, yang terpenting adalah arbiter harus memberikan kesempatan tersebut secara seimbang. ${ }^{34}$

Prinsip selanjutnya berkaitan dengan beban pembuktian. Ketentuan mengenai beban pembuktian dalam arbitrase tidak diatur dalam pasal manapun dalam UU No. 30/1999, baik

30 UNCITRAL Model Law, Op. Cit., Art. 18.

1 Ibid., Art. 23 Paragraph (2).

32 Lihat: Article 23 UNCITRAL Model Law 1985 with Amendments as Adopted in 2006 mendefinisikan secara implisit statement of claim sebagai the claimant shall state the facts supporting his claim, the points at issue and the relief or remedy sought. The parties may submit with their statements all documents they consider to be relevant or may add a reference to the documents or other evidence they will submit.

33 Lihat:Article 23 UNCITRAL Model Law 1985 with Amendments as Adopted in 2006 mendefinisikan secara implisit statement of defence sebagai the respondent shall state his defence in respect of these particulars, unless the parties have otherwise agreed as to the required elements of such statements. The parties may submit with their statements all documents they consider to be relevant or may add a reference to the documents or other evidence they will submit.

34 M. Yahya Harahap I, Op. Cit., h. 188. 
secara implisit maupun secara eksplisit. Begitu pula jika melihat ketentuan yang ada dalam UNCITRAL Model Law, UNCITRAL Model Law tidak mengatur secara tegas mengenai beban pembuktian. Jika dalam UNCITRAL Model Law tidak diatur mengenai beban pembuktian, lain halnya dengan ketentuan yang ada dalam UNCITRAL Arbitration Rules. UNCITRAL Arbitration Rules mengaturnya dalam Article 27paragraph 1 yang menyatakan bahwa "each party shall have the burden of proving the facts relied on to support its claim or defence". Melalui ketentuan tersebut maka UNCITRAL Arbitration Rules telah menentukan secara jelas bahwa baik pihak claimant maupun respondent dapat dikenai beban pembuktian.

Meskipun mengenai beban pembuktian tidak diatur dalam UU No. 30/1999, namun seperti yang sudah dibahas sebelumnya bahwa UU No. 30/1999 melalui Pasal 29 ayat (1) menerapkan prinsip audi et alteram partem, yaitu para pihak yang bersengketa mempunyai hak dan kesempatan yang sama dalam mengemukakan pendapat masing-masing. Dengan menafsirkan pasal tersebut memang tidak dapat disimpulkan mengenai beban pembuktian akan dibebankan kepada siapa, namun melalui pasal tersebut dapat diketahui bahwa kedudukan para pihak adalah sama dan seimbang di hadapan arbiter atau majelis arbitrase. Oleh karena itu, seharusnya prinsip beban pembukitan yang adil dan seimbang dirasa dapat diterapkan di dalam proses pembuktian arbitrase.

Berbeda halnya dengan UU No 30/1999, Peraturan Prosedur BANI justru mengatur secara tegas mengenai beban pembuktian ini, melalui Pasal 23 ayat (1) BANI mengatur mengenai beban pembuktian yaitu sebagai berikut "setiap pihak wajib menjelaskan posisi masing-masing, untuk mengajukan bukti yang menguatkan posisinya dan untuk membuktikan fakta-fakta yang dijadikan dasar tuntutan atau jawaban." ${ }^{35}$ Dengan melihat ketentuan tersebut, maka dapat dikatakan bahwa BANI menerapkan prinsip beban pembuktian yang seimbang, karena ketentuan tersebut memberikan kemungkinan bagi para pihak untuk menjelaskan posisi masing-masing, serta memberikan hak kepada para pihak untuk mengajukan bukti yang berkaitan dengan posisinya masing-masing.

Arbitration Act 1996 yaitu ketentuan yang mengatur mengenai arbitrase di wilayah Inggris, Wales, dan Irlandia Utara juga secara implisit menerapkan prinsip beban pembuktian yang seimbang. Dalam Section 33 paragraph (a) Arbitration Act 1996 diatur bahwa;

"the tribunal must act fairly and impartially as between the parties, giving each party a reasonable opportunity of putting his case and dealing with that of his opponent..." ${ }^{36}$ The section continues: the tribunal must comply with that general duty in conducting the arbitral proceedings, in its decisions on matters of procedure and evidence and in the exercise of all other powers conferred on it. ${ }^{37}$

Dari ketentuan tersebut terlihat bahwa arbiter atau majelis arbitrase harus memperlakukan para pihak secara adil dan seimbang, dan ketentuan tersebut juga berlaku

35 Lihat: Pasal 23 (1) Peraturan Prosedur BANI.

36 Enid A. Marshall, Gill: The Law of Arbitration (Fourth Edition), Sweet \& Maxwell, London, 2001, p. 38.

37 Ibid, p. 39. 
dalam hal pembuktian. Sebagai perbandingan, jika melihat mengenai ketentuan tentang beban pembuktian dalam arbitrase di Singapura sebenarnya hampir sama dengan di Indonesia, yaitu pada dasarnya mengadopsi ketentuan yang berlaku dalam litigasi. ${ }^{38}$ Kurangnya pengaturan yang tegas mengenai "rules of evidence" ini menyebabkan banyak lawyer arbitrase di Singapura justru memilih untuk menerapkan prinsip-prinsip yang ada dalam Evidence Act. ${ }^{39}$

Jika melihat uraian mengenai beban pembuktian di atas, maka dapat dikatakan bahwa ketentuan mengenai beban pembuktian memang seringkali tidak diatur secara tegas. Untuk itu khususnya dalam hal penerapan beban pembuktian, arbiter atau majelis arbitrase seringkali mengadopsi hukum acara perdata yang diterapkan di litigasi. Oleh karena itu, dalam hal beban pembuktian berdasarkan UU No. 30/1999 tidak hanya didasarkan melalui penafsiran pasal-pasal saja. Dikarenakan dalam UU No. 30/1999 tidak diatur, maka harus dilihat terlebih dahulu di dalam perjanjian arbitrase apakah ditulis secara tegas bahwa para pihak sepakat untuk tunduk dalam hukum acara tertentu atau tidak. Jika ternyata tidak disepakati, maka para pihak karena hukum akan tunduk pada ketentuan yang ada dalam UU No. 30/1999.

Proses pemeriksaan perkara dalam arbitrase pada dasarnya juga menggunakan ketentuan-ketentuan yang terdapat dalam hukum acara perdata, maka sekalipun dalam UU No 30/1999 tidak diatur, acuannya adalah dengan melihat pada peraturan perundangundangan yang lebih umum, dalam hal ini mengacu pada ketentuan di dalam BW dan HIR, dimana BW dan HIR sebagai lex generalis dari UU No. 30/1999 sudah mengatur mengenai beban pembuktian ini. Sehingga beban pembuktian berdasarkan UU No. 30/1999 juga seharusnya tidak akan jauh berbeda dengan penerapan beban pembuktian dalam litigasi yang pada dasarnya mengatur bahwa beban pembuktian ada pada yang mendalilkan (siapa yang mendalilkan dialah yang harus membuktikan), namun tetap dengan batasan prinsip yang adil dan seimbang.

Prinsip selanjutnya berkaitan dengan kewajiban menjadi saksi. Berbeda halnya dengan pengaturan mengenai kewajiban menjadi saksi yang diatur secara tegas dalam dalam Pasal 139-143 HIR yang pada prinsipnya menganut sistem bahwa menjadi saksi merupakan kewajiban hukum, maka dalam ketentuan UU No. 30/1999 pengaturan mengenai kewajiban menjadi saksi sama sekali tidak diatur baik secara eksplisit tertulis dalam pasal-pasalnya maupun secara implisit sekalipun. Dalam proses pemeriksaan melalui arbitrase, mekanisme untuk menghadirkan saksi diawali dengan melakukan panggilan kepada para saksi melalui surat panggilan secara langsung oleh arbiter atau majelis arbitrase, atau berdasarkan bantuan para pihak yang mengajukan tuntutan. Surat panggilan yang sah dapat diterbitkan tidak hanya untuk menghadirkan saja, tetapi juga untuk memaksa kehadirannya di hadapan arbiter

38 Leslie Chew, Intoduction to The Law and Practice of Arbitration in Singapore, LexisNexis, 2010, h. 157, lihat Pinsler, Evidence, Advocacy and the Litigation Process, LexisNexis, 2nd ed, p. 260-263.

39 Ibid. 
atau majelis arbitrase dengan membawa dokumen yang dapat dihadirkan. 40 "Ketidakpatuhan yang disengaja terhadap sebuah panggilan yang sah oleh seseorang di dalam yurisdiksi yang bersangkutan dapat dianggap sebagai pelecehan terhadap arbitrase."41

Lalu bagaimana jika kemudian saksi yang berkaitan dengan sengketa yang sedang diperiksa tidak mau datang untuk didengar kesaksiannya, apakah arbiter berwenang memaksa yang bersangkutan untuk dihadirkan di persidangan seperti dalam proses penyelesaian perkara perdata melalui litigasi, atau apakah arbiter dapat menentukan bahwa saksi yang tidak memenuhi kewajibannya itu dapat dihukum dengan membayar biaya dan ganti rugi seperti yang diatur dalam Pasal 140 dan Pasal 141 HIR, hal ini tentu dapat menjadi permasalahan tersendiri, apalagi ketentuan UU No. 30/1999 sama sekali tidak mengatur mengenai kewajiban menjadi saksi dan mekanisme apa yang dapat ditempuh oleh arbiter untuk menyelesaikan permasalahan semacam ini.

Berbeda dengan UU No. 30/1999, UNCITRAL Model Law dengan tegas mengatur mengenai court assistance in taking evidence yang diatur dalam Article 27. Dalam Article 27 ditentukan bahwa "The arbitral tribunal or a party with the approval of the arbitral tribunal may request from a competent court of this State assistance in taking evidence. The court may execute the request within its competence and according to its rules on taking evidence." "42 Jika melihat ketentuan dalam Article 27 tersebut, maka dapat dikatakan bahwa sekalipun dimungkinkan adanya bantuan dari pengadilan, UNCITRAL Model Law tetap menjamin kompetensi dari majelis arbitrase. Sebagaimana secara tegas disebutkan dalam rumusan pasalnya bahwa bantuan tersebut hanya dapat dilakukan dengan persetujuan dari majelis arbitrase (with the approval of the arbitral tribunal). Dengan melihat ketentuan tersebut maka dapat dikatakan bahwa dalam hal "taking evidence" arbiter dapat meminta bantuan dari pengadilan yang memiliki kompetensi. Evidence atau alat bukti ini diartikan sebagai alat bukti yang diakui oleh UNCITRAL Model Law dimana salah satunya adalah alat bukti saksi. Sehingga jika tunduk pada ketentuan yang ada dalam UNCITRAL Model Law maka jika kemudian terjadi permasalahan mengenai kehadiran saksi-saksi dapat digunakan ketentuan pasal tersebut sebagai cara untuk menyelesaikan permasalahan yang berkaitan dengan kehadiran saksi-saksi.

Permasalahan mengenai kehadiran saksi-saksi sangat berkaitan dengan subpoena. Subpoena adalah "A subpoena is a writ, a written order, issued by a court which commands a person to appear in court or before a grand jury, a congressional committee, or administrative agency at a specific place and time. ${ }^{43}$ Subpoena merupakan surat perintah tertulis yang dikeluarkan oleh pengadilan, dengan adanya subpoena tersebut dapat memaksa yang bersangkutan untuk datang menghadap di muka pengadilan sebagai saksi atau untuk

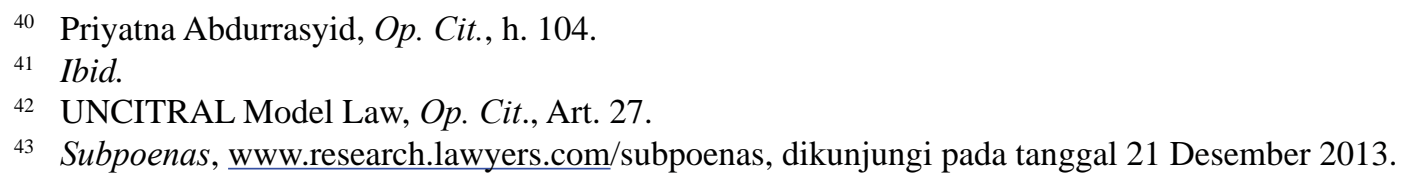


menunjukkan dokumen-dokumen berkaitan dengan proses pemeriksaan di pengadilan. ${ }^{44}$ Terdapat dua macam subpoena yaitu Subpoena ad testificandum dan Subpoena duces tecum. Subpoena ad testificandum yaitu "A subpoena ad testificandum, also known as an ordinary subpoena, literally means "to testify under penalty." It commands a person to appear at a particular location to give testimony. The most common use of a subpoena is to require a witness to attend a trial. "Subpoena ad testificandum merupakan surat perintah tertulis yang memerintahkan seseorang untuk hadir di suatu tempat tertentu untuk memberikan testimoni. Namun jenis subpoena ini umumnya digunakan untuk memaksa seseorang untuk hadir di hadapan pengadilan sebagai saksi. ${ }^{45}$ Sedangkan yang dimaksud dengan subpoena duces tecum yaitu sebagai berikut:

A subpoena duces tecum, also known as a subpoena for production of evidence, literally means "bring with you under penalty." It commands a person to appear at a particular location to bring a specified item for use or examination in a legal proceeding. A recipient of a subpoena duces tecum is commonly required to present documents, such as personal papers and business records, and physical evidence to the court. ${ }^{46}$

Berbeda dengan subpoena ad testificandum yang isinya menghadirkan seseorang dengan kapasitas sebagai saksi untuk memberikan keterangan, subpoena duces tecum merupakan surat perintah tertulis yang isinya memerintahkan yang bersangkutan untuk datang pada tempat tertentu dengan membawa barang tertentu untuk digunakan dalam pemeriksaan yang biasanya berupa dokumen-dokumen bisnis, dokumen-dokumen pribadi, dan barang bukti di pengadilan. Subpoena duces tecum umumnya digunakan dalam penyelesaian perkara perdata, ketika salah satu pihak menolak untuk memberikan dokumen-dokumen yang berkaitan dengan sengketa a quo kepada pihak lainnya pada proses discovery. ${ }^{47}$ Oleh karena itu, jika terdapat permasalahan mengenai kehadiran saksi-saksi dalam perkara perdata khususnya yang diselesaikan melalui arbitrase, seharusnya juga dapat diterapkan mekanisme melalui subpoena ini mengingat UU No. 30/1999 juga memungkinkan adanya discovery. Mekanisme semacam ini seharusnya bisa ditempuh, yaitu dimulai dengan permintaan arbiter kepada pengadilan untuk mengeluarkan subpoena, kemudian pengadilan yang berwenang akan mengeluarkan subpoena untuk memaksa para saksi atau pihak ketiga agar hadir atau menunjukkan dokumen yang dimaksud. Namun, upaya ini tampaknya akan sangat sulit untuk dilakukan, pengadilan tentu akan menolak karena hal ini akan terbentur atau bertentangan dengan ketentuan yang ada dalam Pasal 11 ayat (2) UU No. 30/1999, dimana dalam pasal tersebut dirumuskan sebagai berikut: (2) Pengadilan Negeri wajib menolak dan tidak akan campur tangan di dalam suatu penyelesaian sengketa yang telah ditetapkan melalui arbitase, kecuali dalam hal-hal tertentu yang ditetapkan dalam Undang-undang ini.
44 Ibid.
45 Ibid.
46 Ibid.
47 Ibid. 
Ketentuan Pasal 11 ayat (2) UU No. 30/1999 tersebut menyebabkan arbiter menjadi sangat sulit untuk menggunakan subpoena dalam hal menghadirkan saksi-saksi di hadapan arbiter atau majelis arbitrase atau memaksa pihak ketiga untuk menunjukkan dokumen, karena pengadilan yang seharusnya dapat membantu dengan mengeluarkan subpoenatelah dibatasi kewenangannya dengan adanya ketentuan Pasal 11 ayat (2)UU No. 30/1999.

Sebelumnya telah dibahas bahwa dalam penyelesaian sengketa perdata di bidang dagang dan komersial dikenal adanya perjanjian pembuktian. Perjanjian pembuktian ini juga dikenal dalam arbitrase. Alat bukti yang sah dapat didasarkan atas kesepakatan para pihak. Para pihak dapat menentukan dalam klausula arbitrase baik itu dalam pactum de compromittendo atau akta kompromis, bahwa dalam sengketa yang sedang disengketakan hanya dapat dibuktikan berdasar alat bukti tertentu saja. Misalnya, para pihak bersepakat untuk menggunakan alat bukti tertulis dan keterangan dari para pihak saja, maka dengan adanya klausula tersebut para pihak telah bersepakat untuk mengesampingkan alat bukti lainnya. Klausula ini menyebabkan adanya batasan bagi para pihak untuk mempergunakan alat bukti lain selain daripada alat bukti yang telah disepakati para pihak. ${ }^{48}$

Adanya perjanjian pembuktian yang membolehkan para pihak menyepakati alat bukti serta nilai kekuatan pembuktiannya sebenarnya didasarkan atas adanya asas kebebasan berkontrak sebagaimana diatur dalam Pasal 1338 BW. Sehingga dapat dikatakan pembatasan mengenai alat bukti yang dapat diajukan tidaklah bertentangan dengan hukum asalkan kesepakatan tersebut tidak sampai menghapuskan penggunaan alat bukti secara keseluruhan, atau para pihak menyepakati untuk menggunakan alat bukti lain selain yang diatur secara tegas di dalam undang-undang, ataupun para pihak bersepakat untuk meniadakan kemungkinan adanya bukti lawan. Selama hal-hal tersebut tidak diperjanjikan, maka pada dasarnya tidak ada larangan untuk menentukan sendiri alat bukti apa saja yang dikehendaki para pihak dalam penyelesaian sengketa. Para pihak boleh memilih untuk menggunakan alat bukti apa saja dari sekian alat bukti yang telah diatur dalam berbagai ketentuan hukum nasional atau internasional. ${ }^{49}$

Sehingga, pada dasarnya para pihak memiliki wewenang untuk mengatur bukti lawan, mereka juga dapat menggunakan alat bukti tertentu sebagai bahan untuk pengajuan bukti lawan. Selain itu para pihak juga dapat memperjanjikan suatu jenis alat bukti merupakan satu-satunya alat bukti yang dijadikan dasar pembuktian diantara mereka, para pihak juga dapat memperjanjikan nilai kekuatan pembuktian untuk memberikan bukti lawan. Hal yang paling penting adalah jangan sampai para pihak melarang adanya segala bentuk bukti lawan, karena hal tersebut berlawanan dengan ketertiban umum dan kesusilaan. Adanya perjanjian pembuktian haruslah dilaksanakan berdasarkan itikad baik dari para pihak, dengan begitu akan terbatasi kebebasan para pihak dalam menyepakati perjanjian pembuktian yang

\footnotetext{
48 M. Yahya Harahap I, Op.Cit., h. 191.

49 Ibid, h. 191-192.
} 
sebenarnya sangat berpotensi untuk dijadikan alat bagi para pihak untuk merugikan pihak lainnya jika sampai dilakukan dengan itikad buruk. ${ }^{50}$

Meskipun dimungkinkan adanya perjanjian pembuktian ini, masih terdapat batasanbatasan mengenai alat bukti yang bisa digunakan dalam hal pembuktian tertentu yang memang telah diatur oleh undang-undang. Misalnya pembuktian dalam menutup perjanjian asuransi, alat bukti yang bisa digunakan pada dasarnya adalah polis. Hal ini tertuang secara jelas dalam Pasal 255 KUHD yang menyatakan bahwa "suatu pertanggungan harus dibuat secara tertulis dalam suatu akta yang dinamakan polis." Salah satu fungsi dari polis tersebut adalah sebagai alat bukti tertulis untuk melakukan klaim asuransi. Namun, jika melihat ketentuan yang ada dalam Pasal 258 KUHD, maka sebenarnya masih dimungkinkan untuk menggunakan alat bukti lainnya selain polis dengan ketentuan bahwa sudah ada suatu permulaan pembuktian dengan tulisan.

\section{Kesimpulan}

Arbitrase merupakan bagian dari hukum perdata formil, karena arbitrase juga merupakan penegakan hukum perdata materiil yaitu Hukum Dagang. Oleh karena itu, prinsip umum pembuktian perkara perdata pada umumnya juga berlaku sebagai prinsip pembuktian dalam arbitrase. Merujuk pada ketentuan-ketentuan yang ada di dalam UU No. 30/1999, dimana undang-undang tersebut berkedudukan sebagai lex arbitri di Indonesia.

Prinsip-prinsip pembuktian yang berlaku dalam arbitrase berdasarkan UU No. 30/1999 adalah sebagai berikut: 1) Kedudukan arbiter dalam proses pembuktian arbitrase tidak sepenuhnya bersifat pasif, dimana dimungkinkan bagi arbiter untuk menerapkan prinsip discovery yang sebenarnya lebih umum digunakan dalam sistem hukum common law; 2) Dalam arbitrase juga berlaku prinsip audi alteram partem, sebagaimana terlihat dalam ketentuan Pasal 29 ayat (1) UU No. 30/1999; 3) Beban pembuktian dalam arbitrase tidak diatur dalam pasal manapun dalam UU No. 30/1999, baik secara implisit maupun secara eksplisit, oleh karenanya yang dijadikan acuan adalah ketentuan di dalam BW dan HIR, dimana BW dan HIR sebagai lex generalis dari UU No. 30/1999 pada dasarnya mengatur bahwa beban pembuktian ada pada yang mendalilkan (siapa yang mendalilkan dialah yang harus membuktikan), namun tetap dengan batasan prinsip yang adil dan seimbang; 4) UU No. 30/1999 juga tidak mengatur mengenai kewajiban menjadi saksi. Sehingga timbul permasalahan jika terdapat saksi yang tidak bersedia hadir tanpa alasan yang sah dan jika arbiter meminta pihak ketiga untuk menunjukkan dokumen tertentu, kemudian pihak ketiga tersebut menolak, UU No. 30/1999 tidak memberikan ketentuan yang bisa digunakan arbiter untuk memaksa saksi tersebut untuk hadir atau pihak ketiga tersebut untuk menunjukkan dokumen yang diminta. Sedangkan mekanisme subpoena yang seharusnya menjadi jalan

50 A. Pitlo,Pembuktian dan Daluwarsa: Menurut Kitab Undang-Undang Hukum Perdata Belanda (terjemahan M. Isa Arief), PT. Intermasa, Jakarta, h. 37. 
keluar dari permasalahan ini akan sangat sulit untuk diterapkan, mengingat pengadilan yang memiliki kewenangan untuk mengeluarkan subpoena justru terbatasi dengan adanya ketentuan Pasal 11 ayat (2) UU No. 30/1999. Perjanjian pembuktian juga dikenal dalam arbitrase. Para pihak dapat menentukan dalam klausula arbitrase baik itu dalam pactum de compromittendo atau akta kompromis, bahwa dapat disepakati pembuktian berdasarkan alat bukti tertentu saja, serta dapat pula disepakati mengenai nilai kekuatan pembuktiannya.

\section{Daftar Bacaan}

\section{Buku}

Abdurrasyid, Arbitrase dan Alternatif Penyelesaian Sengketa (APS): Suatu Pengantar (Edisi Ke-2 Revisi), Fikahati Aneska, Jakarta, 2011.

Adolf, Analisis dan Evaluasi Hukum Penyelesaian Sengketa Melalui Arbitrase (UU No. 30 Tahun 1999), Badan Pembinaan Hukum Nasional Departemen Hukum dan HAM RI, Jakarta, 2006.

Chew, Intoduction to The Law and Practice of Arbitration in Singapore, LexisNexis, 2010.

Emson, Evidence, Macmillan, London, 1999.

Harahap, Arbitrase ditinjau dari: RV, Peraturan Prosedur Bani, ICSID, UNCITRAL Arbitration Rules, Convention of the Recognition and Enforcement of Foreign Arbitral Award, Perma No. 1 Tahun 1990, Sinar Grafika, Jakarta, 2003.

--------, Hukum Acara Perdata tentang: Gugatan, Persidangan, Penyitaan, Pembuktian, dan Putusan Pengadilan, Sinar Grafika, Jakarta, 2009.

Margono, ADR (Alternative Dispute Resolution) \& Arbitrase: Proses Pelembagaan dan Aspek Hukum, Ghalia Indonesia, Jakarta, 2000.

Marshall, Gill: The Law of Arbitration (Fourth Edition), Sweet \& Maxwell, London, 2001.

Widjaja, dan Yani, Hukum Arbitrase, Raja Grafindo Persada, Jakarta, 2003.

Pitlo, Pembuktian dan Daluwarsa: Menurut Kitab Undang-Undang Hukum Perdata Belanda (terjemahan M. Isa Arief), PT. Intermasa, Jakarta.

Younger, Goldsmith and Sonenshein, Principles of Evidence: Third Edition, Anderson Publishing Co., Ohio, 1997.

\section{Peraturan Perundang-Undangan}

Burgerlijk Wetboek.

Herzeine Inlandsch Reglement.

Kitab Undang-Undang Hukum Dagang. 
Undang-Undang Nomor 30 Tahun 1999 tentang Arbitrase dan Alternatif Penyelesaian Sengketa, Lembaran Negara Republik Indonesia Tahun 1999 Nomor 138, Tambahan Lembaran Negara Republik Indonesia Nomor 3972.

\section{Peraturan Lainnya}

Peraturan Prosedur BANI

UNCITRAL Model Law on International Commercial Arbitration 1985: with amendments as adopted in 2006, United Nations, Vienna, 2008.

UNCITRAL Arbitration Rules (as Revised in 2010), United Nations, Vienna, 2011.

Arbitration Act 1996 (of England).

French Law on Arbitration, Decree No. 2011-48 of 13.

Law of Malaysia, Act 646 Arbitration Act 2005.

Singapore Act Arbitration 2001.

\section{Prosiding Konferensi}

Winarta, Frans Hendra, Discovery of Documentary Evidence in International Commercial Arbitration, Proceeding Sixth RAIF Conference On International Arbitration Jimbaran, Bali, Indonesia 5-6 May 2012.

\section{Website}

Subpoenas, www.research.lawyers.com/subpoenas, dikunjungi pada tanggal 21 Desember 2013. 